\title{
ARSENIC EXPOSURE THROUGH DRINKING WATER AND ITS EFFECT ON PREGNANCY OUTCOME IN BENGALI WOMEN
}

\author{
Jaydip SEN ${ }^{1}$ and Asit B. D. CHAUDHURI ${ }^{2}$ \\ Department of Anthropology, University of North Bengal, West Bengal ${ }^{1}$, Department of Anthropology, \\ University of Calcutta, West Bengal², India
}

Received in March 2008

Accepted in August 2008

\begin{abstract}
Twelve districts of the state of West Bengal, India are affected by arsenic (As) and millions of individuals are consuming As-contaminated groundwater. The probable adverse effects of As on pregnancy outcome (stillbirth and miscarriage) are yet to be properly studied. The present investigation is an attempt to understand the effects of As exposure on the pregnancy outcome in Bengali women exposed to As through drinking water and residing in different villages in North 24 Parganas District of West Bengal. The results show a significantly higher rate of stillbirths and miscarriages than those in the unexposed population.
\end{abstract}

KEY WORDS: groundwater, miscarriage, stillbirth, toxic elements, West Bengal

Arsenic (As) has been recognised as a human toxicant for over 2000 years. Numerous studies have shown that As has an adverse effect on humans. The element is genotoxic, alters DNA methylation, and adversely affects cell proliferation. It also inhibits certain enzymes and causes tumour, cancer, dermatosis, and arsenicosis. Animal research has demonstrated that As significantly affects developing embryos in avian and mammalian species. This element can readily transfer to the foetus and shows developmental toxicity in animal embryo cultures. It has been recognized as a reproductive toxicant in humans (1).

One of the main routes of As exposure in humans is through drinking water. The primary source of this drinking water is groundwater, which is contaminated with As. Various studies have shown concern that drinking As-contaminated water is a major worldwide public problem (2). In India, one of the most affected regions is the Ganges Delta Plain, and the state of West Bengal in particular (3). Millions of people are affected. The number of affected districts in West Bengal has steadily increased over the years, starting from six in 1994 to twelve districts in 2006, counting. One of the most affected districts is North 24 Parganas. The groundwater As levels in the area are significantly higher than the Indian National drinking water standard of $50 \mathrm{mg} \mathrm{L}^{-1}$ and the provisional limit of $10 \mu \mathrm{g} \mathrm{L}^{-1}$ recommended by the World Health Organization (WHO).

Exposure to As through drinking water may involve the risk of negative pregnancy outcome (stillbirth and miscarriage). But this is yet to be proved conclusively. There are but a few studies on the effects of groundwater As contamination on human reproduction, including a review which was published a decade ago (4). There is, however, growing evidence to suggest that exposure to high concentrations of As during pregnancy increases the risk of stillbirth.

As one of the major routes of As exposure in West Bengal is groundwater, there is an immediate need to address the issues related to As exposure through 
groundwater and effects on pregnancy outcome in this area.

It would be worthwhile to assess the role of As in the incidence of stillbirths and miscarriages among women exposed to As. The hypothesis that is being tested here is that women exposed to As through drinking water have a higher incidence of miscarriages and stillbirths than those unexposed to As.

\section{SUBJECTS AND METHODS}

The data on pregnancy outcome were collected from 240 married women residing in four As-affected villages (Shimulpur, Kamdebkati, Raghabpur, and Chandalhati, $n=60$ per village) located in North 24 Parganas district of the state of West Bengal, India. In these villages there was a number of people suffering from As-related symptoms. All these villages are included in a community-based project to mitigate groundwater As exposure. This project has been conducted by a non-governmental social organisation called Save the Environment, Calcutta in collaboration with All India Institute of Hygiene and Public Health and India-Canada Environment Facility. There is also a specialised clinic to monitor As exposure in the area.

All the women belong to the Bengali Population which consist of the Bengali Hindu Caste and the Bengali Muslims who are genetically identical (5). To obtain information on pregnancy outcome, we used a structured interview The responses were compared with those by 60 control married women from a village called Babla-Gobindapur, located in the nearby district of Nadia. Women from both the As-exposed villages and the control village were randomly selected and made for about one third of the total married female population of each village. Women were further matched for age, socioeconomic status, family size and age at marriage.

Most of the tube wells, which supply drinking water to the residents of the four As-exposed villages have been reported for As water contamination which is significantly higher than the Indian National drinking water standard and the WHO recommended provisional limit. The concentrations of As was determined using standardized field kits recommended by the WHO. The number of stillbirths and miscarriages over the period 1995-2005 were obtained from the study subjects. Chi-square test was used to compare pregnancy outcomes (stillbirths and miscarriages) between the exposed and control subjects.

\section{RESULTS}

Our results show that the exposed women (villages Shimulpur, Kamdebkati, Raghabpur, and Chandalhati) had a higher number of stillbirths and miscarriages than controls (village Babla-Gobindapur). The results are shown in detail in Table 1.

Table 2 shows the chi-square values for both stillbirths and miscarriages in all villages. The differences between each As-exposed village and the control village turned out to be statistically significant ( $p<0.05$; d.f.: 1 ) for all outcomes save for miscarriage between Chandalhati and Babla-Gobindapur.

\section{DISCUSSION}

It has been reported that exposures to toxic elements such as lead and methylmercury could have significant adverse effects on pregnancy $(6,7)$. However, only a limited number of studies have investigated stillbirths and miscarriages among pregnant women exposed

Table 1 Village-wise break-up showing the number of tube wells, number of As-affected tube wells, As levels, number of women investigated, and the number of stillbirths and miscarriages

\begin{tabular}{lcccccc}
\hline Name of village & $\begin{array}{c}\text { Number of } \\
\text { tube-wells }\end{array}$ & $\begin{array}{c}\text { Number of } \\
\text { As-affected } \\
\text { tube-wells }\end{array}$ & $\begin{array}{c}\text { Level of As in } \\
\text { water } / \mathbf{m g ~ L}^{-1}\end{array}$ & $\begin{array}{c}\text { Number } \\
\text { of women } \\
\text { investigated }\end{array}$ & $\begin{array}{c}\text { Number } \\
\text { of } \\
\text { stillbirths }\end{array}$ & $\begin{array}{c}\text { Number of } \\
\text { miscarriages }\end{array}$ \\
\hline Shimulpur & 262 & 251 & $0.01-0.54$ & 60 & 6 & 18 \\
Kamdebkati & 268 & 239 & $0.01-0.60$ & 60 & 7 & 18 \\
Raghabpur & 95 & 59 & $0.01-0.08$ & 60 & 10 & 17 \\
Chandalhati & 136 & 119 & $0.01-0.60$ & 60 & 11 & 22 \\
$\begin{array}{l}\text { Babla-Gobindapur } \\
\text { (control) }\end{array}$ & 180 & 0 & $<0.01$ & 60 & 5 & 8 \\
\hline
\end{tabular}


Table 2 Results of the chi-square tests to estimate statistical differences in stillbirths and miscarriages between women from the exposed and control villages

\begin{tabular}{lcc}
\hline \multirow{2}{*}{ Exposed village vs. control village } & Stillbirths & Miscarriages \\
\cline { 2 - 3 } & chi-square & chi-square \\
\hline Shimulpur vs. Babla-Gobindapur & $0.08^{*}$ & $3.18^{*}$ \\
Kamdebkati vs. Babla-Gobindapur & $0.30^{*}$ & $3.18^{*}$ \\
Raghabpur vs. Babla-Gobindapur & $1.48^{*}$ & $2.69^{*}$ \\
Chandalhati vs. Babla-Gobindapur & $1.99^{*}$ & 5.27 \\
\hline
\end{tabular}

* statistically significant difference $(p<0.05)$

to As through groundwater. Our study suggests that such exposure produces adverse effects on pregnancy outcome, as the incidences of stillbirths and miscarriages significantly differ between the exposed and the control groups. A recent similar study done in West Bengal has suggested that high As exposure through groundwater increases the risk of stillbirth, but not of miscarriage (8). On the other hand, a study in Bangladesh (9) has reported higher incidence of stillbirths and miscarriages in pregnant women exposed to As through groundwater than in normal controls. Our results confirm the findings reported in other similar studies as well (10-12).

Exposure to As causes placental dysmorphogenesis and defective placental vasculogenesis, resulting in placental insufficiency and subsequent miscarriage. This has well been documented in mice, and may apply for humans (13-14). Attention must be paid to comparative pharmacokinetics and metabolism, likely exposure scenarios, and possible mechanisms of action of As. This however calls for more rigorously controlled studies. Ideally, these studies should be longitudinal to understand the effect of continuous increase in As content in groundwater on pregnancy outcome.

\section{CONCLUSION}

In conclusion, further research is clearly needed, particularly on the potential toxicity of As. Current studies reasonably argue that As has a potential to adversely affect human reproduction.

\section{Acknowledgements}

The authors acknowledge the help and cooperation of Save the Environment Calcutta. The study was supported by the University Grants Commission (Grant No.: F.PSW-022/03-04).

\section{REFERENCES}

1. Wang A, Holladay SD, Wolf DC, Ahmed SA, Robertson JL. Reproductive and developmental toxicity of arsenic in rodents: a review. Int J Toxicol 2006;25:319-31.

2. Walvekar RR, Kane SV, Nadkarni MS, Bagwan IN, Chaukar DA, D'Cruz AK. Chronic arsenic poisoning: a global health issue - a report of multiple primary cancers. J Cutan Pathol 2007;34:203-6.

3. Rahman MM, Chowdhury UK, Mukherjee SC, Mondal BK, Paul K, Lodh D, Biswas BK, Chanda CR, Basu GK, Saha KC, Roy S, Das R, Palit SK, Quamruzzaman Q, Chakraborti D. Chronic arsenic toxicity in Bangladesh and West Bengal, India - a review and commentary. J Toxicol Clin Toxicol 2001;39:683-700.

4. Shalat SL, Walker DB, Finnell RH. Role of arsenic as a reproductive toxin with particular attention to neural tube defects. J Toxicol Environ Health 1996;48:25372.

5. Das Chaudhuri AB, Basu S, Chakraborty S. Twinning rate in the Muslim population of West Bengal. Acta Genet Med Gemellol 1993;42:35-9.

6. Bellinger DC. Teratogen update: lead and pregnancy. Birth Defects Res A Clin Mol Teratol 2005;73:40920.

7. Itai Y, Fujino T, Ueno K, Motomatsu Y. An epidemiological study of the incidence of abnormal pregnancy in areas heavily contaminated with methylmercury. Environ Sci 2004;11:83-97.

8. von Ehrenstein OS, Guha Mazumder DN, HiraSmith M, Ghosh N, Yuan Y, Windham G, Ghosh A, Haque R, Lahiri S, Kalman D, Das S, and Smith AH. Pregnancy outcomes, infant mortality, and arsenic in drinking water in West Bengal, India. Am J Epidemiol 2006; 163:662-9.

9. Milton AH, Smith W, Rahman B, Hasan Z, Kulsum U, Dear K, Rakibuddin M, Ali A. Chronic arsenic exposure and adverse pregnancy outcomes in Bangladesh. Epidemiology 2005;16:82-6.

10. Rahman A, Vahter M, Ekström EC, Rahman M, Golam Mustafa AH, Wahed MA, Yunus M, Persson LA. Association of arsenic exposure during pregnancy with fetal loss and infant death: a cohort study in Bangladesh. Am J Epidemiol 2007;165:1389-96. 
11. Mukherjee SC, Saha KC, Pati S, Dutta RN, Rahman MM, Sengupta MK, Ahamed S, Lodh D, Das B, Hossain MA, Nayak B, Mukherjee A, Chakraborti D, Dulta SK, Palit SK, Kaies I, Barua AK, Asad KA. Murshidabad - one of the nine groundwater arsenic-affected districts of West Bengal, India. Part II: dermatological, neurological, and obstetric findings. Clin Toxicol 2005;43:835-48.

12. Ahmad SA, Sayed MH, Barua S, Khan MH, Faruquee MH, Jalil A, Hadi SA, Talukder HK. Arsenic in drinking water and pregnancy outcomes. Environ Health Perspect 2001;109:629-31.
13. He W, Greenwell RJ, Brooks DM, Calderón-Garcidueñas L, Beall HD, Coffin JD. Arsenic exposure in pregnant mice disrupts placental vasculogenesis and causes spontaneous abortion. Toxicol Sci 2007;99:24453.

14. Waalkes MP, Liu J, Ward JM, Diwan BA. Animal models for arsenic carcinogenesis: inorganic arsenic is a transplacental carcinogen in mice. Toxicol Appl Pharmacol 2004;198:377-84. 


\section{Sažetak}

\section{IZLOŽENOST ARSENU U PITKOJ VODI I NJEGOV UTJECAJ NA ISHOD TRUDNOĆE U ŽENA IZ ZAPADNOG BENGALA, INDIJA}

Arsenu (As) iz podzemnih voda izloženi su milijuni ljudi koji žive u dvanaest administrativnih jedinica Zapadnoga Bengala u Indiji. Njegovo štetno djelovanje na ishod trudnoće (mrtvorođenja i spontane pobačaje) tek treba kvalitetno dokumentirati. Istražen je utjecaj izloženosti arsenu na ishod trudnoće u bengalskih žena koje su mu bile izložene putem pitke vode, a stanovnice su različitih sela u administrativnoj jedinici North 24 Parganas savezne države Zapadni Bengal. Rezultati istraživanja pokazali su značajno veću učestalost mrtvorođenja i spontanih pobačaja u žena izloženih arsenu u odnosu na neizloženu skupinu.

KLJUČNE RIJEČI: podzemne vode, mrtuorođenje, spontani pobačaj, toksični elementi

\section{CORRESPONDING AUTHOR:}

Jaydip Sen, Associate Professor Department of Anthropology, University of North Bengal P.O. NBU, Raja Rammohunpur, Darjeeling, West Bengal, India E-mail:jaydipsen@rediffmail.com 